\title{
WestVirginiaUniversity。
}

Department of Economics

Working Paper Series

\section{Professional Sports Events, \\ Concerts, and Urban Place Based \\ Policy: Evidence from the Staples \\ Center}

Yulia Chikish

Brad R. Humphreys

Crocker H. Liu

Adam Nowak

Working Paper No. 17-32

This paper can be found at the College of Business and Economics Working Paper Series homepage: 


\title{
Professional Sports Events, Concerts, and Urban Place Based Policy: Evidence from the Staples Center
}

\author{
Yulia Chikish* \\ West Virginia University
}

\author{
Brad R. Humphreys ${ }^{\dagger}$ \\ West Virginia University \\ Adam Nowak ${ }^{\S}$ \\ West Virginia University
}

November 20, 2017

\author{
Crocker H. Liu \\ Cornell University
}

\begin{abstract}
We analyze the relationship between sports events and concerts, important hospitality demand drivers and key components of many urban renewal projects, in the Staples Center in Los Angeles, an arena home to three pro teams, and nearby hotel performance, exploiting exogenous daily variation in the timing of games and concerts from 2002 to 2017. Results show a small positive impact on revenue per available room at hotels within one mile of the arena and an offsetting decrease at hotels located one to four miles away. Granting nearby hotels exemptions from Los Angeles hotel taxes reduces potential tourism-generated hotel tax revenue increases.
\end{abstract}

Key words: place based policy, hotel operating performance, professional sports

JEL Codes: H71, Z23, Z28

\section{Introduction}

Sports-driven tourism could represent an important component of urban economic development projects. Professional sporting events draw large crowds to a specific urban area on game day. For example, National Hockey League (NHL) and National Basketball Association (NBA) games can attract upwards of 20,000 fans, and these teams play more than 40 home games each season, counting exhibition and playoff games. Basketball and hockey arenas also host concerts that draw large crowds. Some consumers attending these events come from out of town, and may rent hotel

\footnotetext{
${ }^{*}$ College of Business \& Economics, 1601 University Ave., PO Box 6025, Morgantown, WV 26506-6025, USA; Email: iuchikish@mix.wvu.edu.

${ }^{\dagger}$ College of Business \& Economics, 1601 University Ave., PO Box 6025, Morgantown, WV 26506-6025, USA; Email: brhumphreys@mail.wvu.edu. We thank Brian Soebbing for valuable comments on this paper.

${ }^{\ddagger}$ Robert A. Beck Professor of Hospitality Financial Management Real Estate, Cornell University School of Hotel Administration, 440 Statler Hall, Ithaca, NY 14853. Email: chl62@cornell.edu.

${ }^{\S}$ College of Business \& Economics, 1601 University Ave., PO Box 6025, Morgantown, WV 26506-6025, USA; Email: adam.d.nowak@gmail.com.
} 
rooms near the arenas on one or more days around the events. If this economic activity represents new spending that would not have taken place absent the staging of sporting events or concerts, then the local economy could benefit economically from these events, as long as the staging of these events does not lead other consumers who would have visited the area to alter their plans.

The effect of sporting events and concerts on tourism-related economic outcomes also has important public policy implications. Many urban revitalization projects feature development of new tourism and consumption centers in underdeveloped neighborhoods, a place-based urban economic policy. Evidence on the effectiveness of such policies is mixed (Busso et al., 2013).

Many new sports facility construction projects are financed using hotel room or revenue taxes. The (then) San Diego Chargers left for Los Angeles in 2016 because the local government would not raise the hotel tax from $12.5 \%$ to $16.5 \%$ to finance a proposed $\$ 1.8$ billion new stadium. The State of Nevada is financing the construction of a new football stadium in Las Vegas through a hotel room tax rate increase of 0.88 percentage points on rooms rented in nearby hotels. The extent to which sporting events and concerts increase hotel room occupancy and revenue will affect the amount of tax revenues raised. Little evidence exists on the impact of sporting events on hotel occupancy and revenues.

A small, growing literature examines the determinants of sport-related urban tourism with an emphasis on factors like tourism clusters, sporting events, conventions, and local shocks to the economy. These papers use high frequency data and exploit spatial proximity to identify the impact of these external factors.

Kosová and Enz (2012) analyze the impact of the 9/11 terrorist attacks and the 2008 financial crisis, shocks that clearly impact tourism, on urban tourism in New York City and find substantial negative impacts. Peiró-Signes et al. (2015) analyze the impact of tourism clusters, identified by large values of the Location Quotient (LQ) measure of firm concentration in the Arts, Entertainment, and Recreation (NAICS 71) and Accommodation and Food Services (NAICS 72) industries, in specific ZIP codes in US cities. They find that hotels located in tourism clusters preform better than hotels located in other ZIP codes. Depken II and Stephenson (2016) analyze the impact of sporting events (NFL and NBA games, PGA golf tournaments, NASCAR races, and college sporting events), conventions, and other specific events on daily hotel operating performance measures in Charlotte, North Carolina. They find a heterogenous impact of these events on urban tourism with substantial temporal and spatial variation, and variation across types of events. Claims that nearby hotels benefit from professional sporting events are not supported by this evidence.

The theoretical link between entertainment events like games and concerts and tourism-related urban economic outcomes is straightforward. Professional sports events and concerts attract large numbers of attendees. The capacity of the Staples Center is more than 18,000 for basketball and hockey games and about 20,000 for concerts; large numbers of tickets are sold for these events. The schedule of games in both leagues are set months in advance. Attendees at these events can be either local residents, fans who travel to see an event in another city, or tourists who happen to be in a city when an entertainment event occurs and decide to attend. The latter two groups may 
stay in a hotel near the arena, leading to increased numbers of hotel rooms rented. To the extent that some attendees are tourists, the presence of these events can increase local demand for hotel rooms.

If out-of-town attendees stay in nearby hotels, then these hotels would benefit economically from this increase in demand. While out of town fans might have specific hotel preferences, based on hotel characteristics like location, amenities, and price, the presence of large numbers of out of town attendees attracted to a specific venue like the Staples Center would affect overall hotel operating performance; out of town visitors have to stay somewhere. For this reason, we analyze outcomes aggregated across hotels in specific geographic areas near the arena, and not outcomes at specific hotels. The vast majority of fans attending events in the Staples Center could be local residents. If this is the case, then the operating performance of nearby hotels would not change in response to the number of events in the arena. Local fans simply drive or take public transport to and from the arena, and do not require lodging as part of their game attendance.

We analyze the impact of regular season NHL games, NBA games, and concerts held in the Staples Center in Los Angeles - the most intensely utilized professional sports venue in the United States - on nearby hotel occupancy and revenues. The scheduling of NBA and NHL games reflects a complex, nationwide process that should be uncorrelated with unobservable local factors in Los Angeles that affect hotel operating performance. We find no evidence that NHL games, NBA games, or concerts had an overall positive effect on average daily room rate, occupancy rate, or revenue per available room at hotels within four miles of the Staples Center. Hotels within one mile experienced small increases in revenue per available room, but this increase was offset by decreases in revenue per available room at hotels located between one and four miles of the arena. A number of hotels near the Staples Center were granted 20 year waivers from the 14\% Transient Occupancy Tax levied on all lodgings in Los Angeles; while hotels near the Staples Center benefit from sporting events and concerts in the Staples Center, local tax revenues may not increase because of these hotel tax waivers. The results call into question the idea that sport-led tourism can benefit the hotel industry, generate net tangible economic benefits, or raise substantial tax revenues through increases in nearby hotel room revenues.

\section{Related Literature}

Sports and entertainment events can affect many urban outcomes, including crime (Montolio and Planells-Struse, 2016), property values (Humphreys and Nowak, 2017; Boualam, 2014), rent (Carlino and Coulson, 2004), and potentially local economic growth (Nitsch and Wendland, 2017). Relatively little research exists analyzing the relationship between major league sports events in North America and urban sport-related tourism. Lavoie and Rodrguez (2005) analyze the relationship between hotel occupancy rates and NHL and NBA games in eight Canadian cities (Vancouver, Calgary, Edmonton, Winnipeg, Toronto, Ottawa, Montreal and Quebec City) using monthly data over the period January 1990 to December 1999. City-wide average hotel occupancy rate data came 
from Canadian Lodging Outlook, an industry publication from the Canadian Hotels Association. Several work stoppages occurred in the NHL, NBA, and MLB over this period, and several cities lost or gained NHL and NBA teams because of league expansions and team relocation.

Lavoie and Rodrguez (2005) create dummy variables for these events and include them in a Box-Jenkins time series model that explains variation in hotel occupancy rates using lagged values of the dependent variable and these dummy variables. The dummy variables reflect the presence of a team in an city, or the occurrence of a work stoppage, but not the number of games played by teams or lost through work stoppages, or attendance at these games. Lavoie and Rodrguez (2005) found that hotel occupancy rates in Montreal, Ottawa, and Quebec City were lower during the 1994 NHL lockout, which lasted three months, but no evidence that hotel occupancy rates increased when a major league team arrived in a Canadian city.

Rishe (2014) analyzes the relationship between mobile sports events (the Super Bowl, NCAA Men's Basketball Final Four, and major professional golf tournaments) and a four different daily hotel outcome variables (occupancy rates, total revenues, )in 40 US cities that hosted 53 mobile sports events over the period 2008-2014. Rishe (2014) compares occupancy and revenues during the week each event was held to occupancy rates and hotel revenues in the same period the year before and year after the event was held. All these sports events last only a few days, so this analysis focuses on the short run impact of large sports events. Rishe (2014) reports substantial increases in occupancy rates and total revenues associated with the hosting of these mobile sports events, particularly Super Bowls. Hotel occupancy rates in Indianapolis for the week of the 2012 Super Bowl increased by $250 \%$ relative to the same weekend the year before and the year after. However, the increased occupancy rates associated with the 2010 Super Bowl in Miami and the 2014 Super Bowl in New York City were only 19\% compared to the same weekends the year before and the year after the event. Total hotel revenues also increased substantially, due to increased occupancy rates and increased room rates. Large sports events like the Super Bowl can clearly have a substantial transitory impact on hotel occupancy rates and revenues near the host venues.

Dermody et al. (2003) perform a similar analysis, investigating how hotel occupancy rates, average daily room rates, and revenue per available room changed on the Saturday night before NFL home games in the 2000 season. Dermody et al. (2003) perform an unconditional comparison of these three outcome variables on Saturday nights before Sunday home and away games, pooling observations for September and October, and for November and December, to account for seasonality. This study finds evidence that hotels near NFL stadiums in a few cities, notably Chicago, Cleveland, and Seattle, had substantially higher revenues on home game weekends, while hotels near NFL stadiums in other cities experienced relatively little revenue impact on home game weekends. This study did not account for variation in attendance at NFL games, or attempt to control for other observable factors affecting hotel revenues.

Collins and Stephenson (2016) undertake a case study of the relationship between minor league baseball games, a small time (NAIA) college football championship game, a regional tennis tournament, and other non-sports events on hotel operating performance in Rome Georgia over the period 
1 January 2005 through 31 December 2013 using daily frequency data. Results using both indicator variables for events and attendance show modest increases in hotel occupancy and total revenues associated with the championship football game (about 1 additional room-night for every 20 attendees) and the tennis tournament (about 1 additional room-night for every three participants) but no impact on room-nights from minor league baseball games or attendees.

Depken II and Stephenson (2016) analyze the relationship between a number of sports events (NFL and NBA regular season and postseason games, NASCAR races, college football and basketball games, PGA Tour events, and marathons) and large scale non-sports events (political conventions, and NRA convention) on hotel outcome variables in Charlotte, North Carolina over the period 2005-2013 using daily frequency hotel data. Depken II and Stephenson (2016) aggregated hotel-specific data across ZIP codes and other geographic areas that generated observations for three distinct areas: all hotels in the center of Charlotte, all hotels within the political boundaries of the city of Charlotte, and all hotels in suburban Charlotte.

Depken II and Stephenson (2016) focus on room-nights, average daily room rates, and total revenues, not occupancy rates. The use of daily frequency data allows for an analysis of impacts of these events before and after they occur; empirical models include indicator variables for the event days and two days before and after the events. NASCAR races increase room-nights sold on race day and the day before, average daily room rates and total revenues. But room-nights sold and revenues decline in the two days following NASCAR events, substantially reducing the net impact of NASCAR races on local hotel operating performance. NFL regular season games and college bowl games increase room-nights sold, average daily room rates and total revenues on game day and the day before, consistent with the results in Dermody et al. (2003). The NASCAR, NFL and college bowl game impacts occur city-wide; they are not concentrated in any specific area. NBA regular season games decrease occupancy, average daily rates, and revenues on game days; these effects occur only in the near and far suburbs, not in the city center. NBA games do not have an impact on hotel operating performance on days before or after games occur. NBA and NFL post season games have no effect on hotel operating performance anywhere in the city at any time.

Both Collins and Stephenson (2016) and Depken II and Stephenson (2016) include the national unemployment rate and the real price of unleaded gas per gallon in order to control for broader economics conditions affecting travel costs and demand for sporting events. These variables are only weakly related to hotel operating performance; both papers report a negative relationship between national unemployment rates and daily hotel revenues. College basketball tournaments have little impact.

Overall, this literature contains mixed results. Large mobile events like the Super Bowl and the Final Four increase hotel occupancy rates and revenues for a short period of time around these events. NFL home games and NASCAR races also increase hotel operating performance on game day, and to a lesser extent one day before games are played. NBA games, college basketball tournaments, and minor league baseball appear to have no impact on hotel operating performance. Large mobile events, NFL games, college bowl games and NASCAR races occur infrequently and 
primarily on weekends. Fans and travelers know about these events long in advance, and travel on weekends involves lower opportunity costs. These events could be expected to increase room occupancy rates. NBA games and minor league baseball games occur much more frequently and throughout the week. Despite advanced knowledge of the regular season schedule, these events appear to attract relatively few out of town visitors.

A growing literature analyzed the impact of other economic factors on hotel operating performance. Kosová and Enz (2012) analyze the impact of external shock generated by the 9/11 terrorist attacks and the 2008 financial crisis on hotel operating performance and found that these events had sizable impacts on occupancy rates, average daily room rates, and revenue per available room. Kosová et al. (2013) analyzed differences in performance of franchised and unfranchised hotels and found little difference in occupancy, room rates, and revenue per available room. These differences are attributed to endogenous choice of organizational form.

Peiró-Signes et al. (2015) analyzed the effect of tourism clusters, a geographic concentration of interrelated firms in the tourism and hospitality industry, on hotel operating performance. LA Live and the Staples Center represent a tourism cluster. They find that hotels located in or near tourism clusters perform better than hotels located outside these areas in terms of occupancy rates, average daily room rates, and revenue per available room; proximity to the cluster and urban location enhance performance. Hua and Yang (2017) analyzed the effect of crime on hotel operating performance in Houston over the period January 2009 to December 2014. They reported that violent crime had a negative impact on revenue per available room.

In general, the literature on the impact of external events on hotel operating performance uses monthly operating performance data, most commonly occupancy, average daily rates, and revenue per available room, from specific metropolitan areas or specific hotels, and estimates reduced form empirical models explaining observed variation in hotel operating indicators. These empirical models include fixed-effects terms to control for unobserved heterogeneity over time and across areas, and generally conclude that many external economic factors affect hotel operating performance.

\section{Staples Center and LA Live}

The Staples Center opened on 17 October 1999 and is home to three major league sports teams: the Los Angeles Lakers and Clippers of the NBA and the Los Angeles Kings of the NHL. ${ }^{1}$ The arena was privately financed and cost $\$ 375$ million to build (about $\$ 554$ million in 2017 dollars). It seats 20,000 for concerts and about 19,000 for basketball and hockey. As the home to three major league teams, it is the most intensively used sports arena in the country in terms of NHL and NBA games. The arena contains 950,000 square feet of event space and 175 suites.

The Staples Center is located adjacent to L.A. Live, a $5+$ million square foot entertainment complex containing concert halls, theatres, restaurants, hotels, and office space. The L.A. Live complex covers 27 acres and represents a major entertainment destination in downtown Los Angeles;

\footnotetext{
${ }^{1}$ It is also home to the LA Sparks WNBA team. WNBA teams play only 16-17 home games per year during May-September and draw smaller crowds than NBA and NHL games. We do not include the Sparks in this analysis.
} 
Phase I which included a larger theatre and a number of retail outlets opened in October 2007 and Phase II, which included several large hotels opened in early 2010. The primary developer was the Anschutz Entertainment Group (AEG), which also owns the Los Angeles Kings NHL team that plays in the Staples Center.

Like the Staples Center, the financing for the construction of the L.A. Live complex was largely private. The L.A. Live complex cost about $\$ 2.5$ billion to build, and received only about $\$ 30$ million in direct public subsidies. However, several hotels that opened adjacent the L.A. Live complex received 20 year waivers from the Los Angeles Transient Occupancy Tax, a local hotel tax which is described below. These waivers had an estimated value of more than $\$ 100$ million over 20 years.

L.A. Live and the Staples Center are also located adjacent to the Los Angeles Convention Center, one of the largest convention centers in the US with 720,000 square feet of exhibition space, 147,000 square feet of meeting space and 1,960,000 square feet of parking spaces. The Staples Center, L.A. Live, and the Convention Center constitute a tourism cluster aimed at attracting large numbers of locals and out of town visitors to a specific part of Los Angeles.

The Staples Center/L.A. Live complex represents an urban place based policy aimed at revitalizing a specific area in Los Angeles. Unlike the urban Empowerment Zone (EZ) program and other urban placed based policies that focused on job creation, this project focused on developing a major center for consumption and tourism by combining a sports arena, convention center, concert theatre, restaurants, and hotels in a small area. Rather than directly encouraging job creation like the EZ program (Busso et al., 2013), Los Angeles clearly intended to concentrate both local consumer and tourist spending in a previously undeveloped area south of Downtown Los Angeles. Absent any net new local consumption spending or tourist inflows, this type of place based policy can redirect existing economic activity to a different neighborhood, underscoring the importance of accounting for the spatial dimension of local economic activity in any empirical analysis.

Several light rail stops are also located near the Staples Center/L.A. Live complex. Public transport access affects consumer demand and commercial property values (Cohen and Brown, 2017). However, public transit access should have a limited impact on sport-tourism-related hotel performance to the extent that proximity to the arena represents an important factor in consumer hotel choice.

The Staples Center/L.A. Live complex represents an ideal setting for an analysis of the effect of professional sporting events on outcomes related to urban tourism. Three professional teams call the Staples Center home. While the Los Angeles metro area has two Major League Baseball (MLB) teams, the Los Angeles Dodgers and the Anaheim Angels, the MLB regular season does not overlap with the NBA or NHL regular season, so the results will not be influenced by omitted variables related to other professional sporting events in the area. The National Football League (NFL) regular season does overlap with the NBA and NHL regular seasons. However, Los Angeles did not have an NFL team during the period analyzed here.

This setting also has important public finance implications. The City of Los Angeles collects 
a 14\% Transient Occupancy Tax (TOT) on rent or room charges on all transient visitors, defined as persons staying in a hotel or other lodging less than 30 days. The Staples Center and the L.A. Live complex was built using private financing, so hotel occupancy tax revenues were not used to finance its construction. However, hotel occupancy taxes have been used to finance the construction of other professional sports facilities across the country, and supporters of public subsidies for the construction of professional sports facilities often tout sports-related travel as an important new source of hotel tax revenues.

Also, several hotels near the Staples Center/L.A. Live complex were exempted from the TOT for 20 years. A better understanding of the relationship between NBA and NHL games played in the Staples Center and nearby hotel operating performance, and spatial patterns of hotel operating performance, provide important context for understanding the effectiveness of hotel occupancy taxes and their general use to finance tourist-related urban economic development plans.

\section{Empirical Methods}

We estimate the following empirical regression model explaining observed spatial variation in daily hotel operating performance

$$
O C_{i d m y}=\alpha_{0}+\alpha_{1} G_{d m y}+\alpha_{2} \text { Lockout }_{d m y}+\sum_{i=1}^{I} \beta_{i} D_{i}+\rho_{d}+\theta_{m}+\tau_{y}+\epsilon_{i d m y} .
$$

The dependent variable $(O C)$ is a hotel operating performance measure aggregated across all hotels in donut $D_{i}, 1=1, \ldots, 3$ on day $d$ during month $m$ of a year $y$. We analyze observed variation in three hotel operating performance variables: occupancy rate, average daily room rate (ADR), and revenue per available room.

The hotel-related data are aggregated into three categories based on proximity to the Staples Center/L.A. Live complex: hotels located within a 1 mile radius of the arena complex, hotels located within 1 - 2.49 miles, and hotels located within 2.5 miles and 5 miles of the arena complex. We call these discrete geographic areas centered on the arena complex "donuts" and identify them with a vector of indicator variables $D_{i}$. Figure 1 shows the Staples Center/LA Live complex, the hotels in our sample, and the three donuts. A large number of hotels are clustered near the Staples Center/LA Live location, primarily north of the complex.

Hotels located in different donuts might have different time invariant characteristics. For example, from Table 2, hotels located within 1 mile of the Staples Center have on average higher daily rates and higher revenue per rooms available compared hotels in all other donuts. We include a set of indicator variables in Equation (1) to account for possible differences in characteristics of hotels in different donuts. The hotels located within a 1 mile radius of the Staples Center form the reference group.

The key explanatory variables of interest are indicator variables for days in which NBA and NHL games or concerts occurred in the Staples Center during month $m$ of year $y$. We estimate Equation 
(1) separately for the occurrence of Los Angeles Kings' home games which constitutes the NHL Game indicator variable and for the occurrence of Los Angeles Clippers and Los Angeles Lakers' home games which constitute the NBA Game indicator variable. Finally, we use the indicator variable for any NHL and NBA game played in the Staples Center on a specific day in each month which constitutes the All Games indicator variable. We also estimate regression models where $G_{d m y}$ is defined as total attendance at NHL and NBA games played in the Staples Center.

Note that the number and timing of NBA and NHL games scheduled in the Staples Center in each season is outside the control of the teams, and outside the control of hotels. Each NHL and NBA team plays 41 home games during the regular season. The details of regular season schedules are set by the league offices, in consultation with individual teams and facilities. An enormous number of factors affect the exact nature of the league schedule, including league rules about which other teams each team must play, team travel schedules, other events scheduled in arenas, traditional games played by specific teams on certain holidays, and other factors. League schedules are set months in advance of the start of the regular season and are not usually changed after the start of the season. Month-to-month variation in the number of home games played by NBA and NHL teams are plausibly exogenous in this context. It is very unlikely that the number of NBA and NHL games scheduled in different months of the season would be systematically correlated with unobservable, time varying factors that affect outcomes in the Los Angeles hotel market. ${ }^{2}$ The scheduling of concerts should also be uncorrelated with unobservable factors affecting hotel performance. Concerts depend on the touring schedules of artists and availability of the arena.

The time frame of our sample includes three periods of work stoppages in the NBA and NHL that led to the cancellation of significant numbers of games. Players in both leagues are unionized, and all terms of employment are determined by collective bargaining agreements (CBAs) negotiated between player unions and teams. CBAs typically last 5-6 years and are re-negotiated on expiry. While many CBAs are easily renegotiated, occasionally disputes arise which delays the passage of a new CBA through collective bargaining. In these cases, a work stoppage may occur. A work stoppage initiated by firms is called a lockout and a work stoppage initiated by employees is called a strike.

Two NHL lockouts occurred during this sample period because of labor disputes between the NHL and the National Hockey League Players' Association (NHLPA). The lockout of 2004-2005 resulted in the cancellation of the entire NHL season, what would have been the 88th season of play in the league. This unprecedented event occurred at the end of a CBA when the league wanted to impose a cap on player salaries. The dispute was not resolved for an entire year, leading to the cancellation of the entire season. The 2012-13 NHL lockout shortened the NHL season by 3 months - it was supposed to begin in October 2012 but began in January 2013. This lockout occurred after the expiration of the CBA signed after the 2004-2005 lockout.

\footnotetext{
${ }^{2}$ We do not include indicator variables for NBA or NHL All Star Games that were played in the Staples Center over the sample period. The Staples Center hosted the NHL/NBA All Star Games in 2002, 2004, 2011 and 2017. While these games attract substantial media attention and potentially many out of town visitors, they occur infrequently and regular season games are not played during the days surrounding these mid-season events.
} 
In 2011 an NBA lockout delayed the beginning of the regular season by about 2 months - the season started on 25 December instead of in early November 2011. To account for the effect of lockouts on NHL and NBA games played, we include dummy variable Lockout dmy $_{\text {which takes a }}$ value 1 if an NHL or NBA lockout took place during day $d$ in month $m$ of year $y$ and takes value 0 otherwise.

Note that these lockouts represent "natural experiments" for assessing the impact of pro sports games on nearby hotel operating performance. They occur because of events unrelated to tourism, or to factors in the market for hotel rooms in Los Angeles. Because the occurrence and length of work stoppages cannot be predicted, they represent random events that could affect demand for hotel rooms in Los Angeles.

The hotel industry is characterized by seasonal variation in demand, which is a crucial component of customer behavior, and therefore can affect operating performance. Also, the Staples Center/LA Live/Los Angeles Convention Center hosts a large number of other entertainment and business events throughout the year, as well as attracting locals to restaurants, and other cultural events. The impact of these factors on hotel operating performance needs to be controlled for to capture normal market conditions in the area. To control for seasonality and other normal local market conditions we include day-of-week fixed effects $\rho_{d}$ and month fixed effects $\theta_{m}$ in the regression models. Finally, we include year fixed effects $\tau_{y}$ to account for common factors that affect the dependent variables which cannot be attributed to the other explanatory variables. For example, the emergence of Airbnb rentals as a substitute for hotel rooms, business cycle effects, and other factors that affect all hotels in the sample.

Hotels located in different donuts might have a different impact on variation in the number of games or attendance at games in the Staples Center. For example, people attending NHL or NBA games might prefer to stay in hotels located closer to the arena. To allow for this possibility we estimate the following regression model which includes interaction terms between number of games and donut dummy variables:

$$
O C_{i d m y}=\alpha_{0}+\alpha_{1} G_{d m y}+\alpha_{2} \text { Lockout }_{d m y}+\sum_{i=1}^{I} \beta_{i} D_{i}+\sum_{i=1}^{I} \gamma_{i} D_{i} G_{d m y}+\rho_{d}+\theta_{m}+\tau_{y}+\epsilon_{i d m y}
$$

Equation (2) contains the same variables as Equation (1). The $\sum_{i=1}^{I} \gamma_{i} D_{i} G_{m y}$ terms capture interaction effects between the occurrence of, or attendance at, concerts, NBA and NHL games and proximity to the Staples Center. The $\gamma_{i}$ parameters capture these interaction effects.

\section{Data}

The hotel operating performance data come from Smith Travel Research (STR), a firm specializing in collection of data from the hotel industry. ${ }^{3}$ The daily hotel operating data cover the period 1 January 2002 to 31 March 2017, more than 16,000 days. We analyze daily variation in three

\footnotetext{
${ }^{3}$ We thank Steve Hood and Duane Vinson from Smith Travel Research for providing the hotel data for this study.
} 
specific measures of hotel operating performance: occupancy rate, average room rate, and revenue per available room. Occupancy rate is rooms sold divided by rooms available, a measure of both demand for rooms and supply of rooms. Complementary rooms are excluded from this variable. Average daily room rate is room revenue divided by rooms sold. Revenue per room available is simply room revenue divided by rooms available. These three operating performance measures are widely used in the literature (Kosová and Enz, 2012; Peiró-Signes et al., 2015; Hua and Yang, 2017).

The hotel data were augmented with data on the timing and characteristics of regular season home games played by the Lakers and Clippers (NBA) and Kings (NHL) and concerts held in the Staples Center over the sample period. We focus on regular season home games because the exact date and opponent in these contests is known in advance, facilitating possible travel to attend these games. Specifics about postseason games are not known in advance, which may limit the ability of out-of-town fans to travel to these games. Depken II and Stephenson (2016) find no relationship between postseason games and hotel room-nights sold in Charlotte and the exact date and opponent for postseason games are not known until a few days before the games are played, making out-of-town travel to games difficult.

Figure 1 shows the location of the Staples Center/L.A. Live complex, the locations of hotels in the sample, and the donuts that form the units of aggregation for the hotel operating performance data. The Staples Center/L.A. Live complex lies at the center of the donuts and red dots identify hotels. Most of the hotels are located to the north and west of the arena complex, toward downtown Los Angeles. Very few hotels are located to the south of the arena.

The sample contains 139 total hotels. Some new hotel openings and hotel closings occur over the sample period, but the hotel operating performance data are spatially aggregated; we do not have operating performance data for individual hotels. The hotels are relatively uniformly spread out across the donuts, given that the donuts increase in area with distance from the arena. Hotels per donut are 49,60, and 30 moving from donut 1 to donut 3. Most of these hotels, $65 \%$, fall into the "Economy" Class of hotels defined by STR. $20 \%$ fall into the "Upscale," "Upper Upscale" or "Luxury" classes; most of these upscale hotels are close to the arena.

Table 1 contains summary statistics for the Staples Center event indicator variables and the hotel operating performance variables. The temporal unit of observation for the summary statistics shown on Table 1 is a day. During the NBA regular season, roughly October to April, an average of 6 Lakers and 6 Clippers home games were played each month in the Staples Center. However, a substantial amount of variation occurred across months, with some months containing no Clippers games or only one Lakers game, and other months containing as many as 11 or 12 Lakers or Clippers games and as many as 20 total NBA games. This provides substantial variation in games to explain observed variation in hotel operating performance.

The NBA lockout accounted for about $3 \%$ of the days in the sample. NHL lockouts accounted for about $14 \%$ of the regular season months in the sample. While this may seem large, the NHL lost the entire 2004-05 season, and part of the 2012-13 season to work stoppages. These lockout 
Figure 1: The Staples Center, Hotels, and Donuts

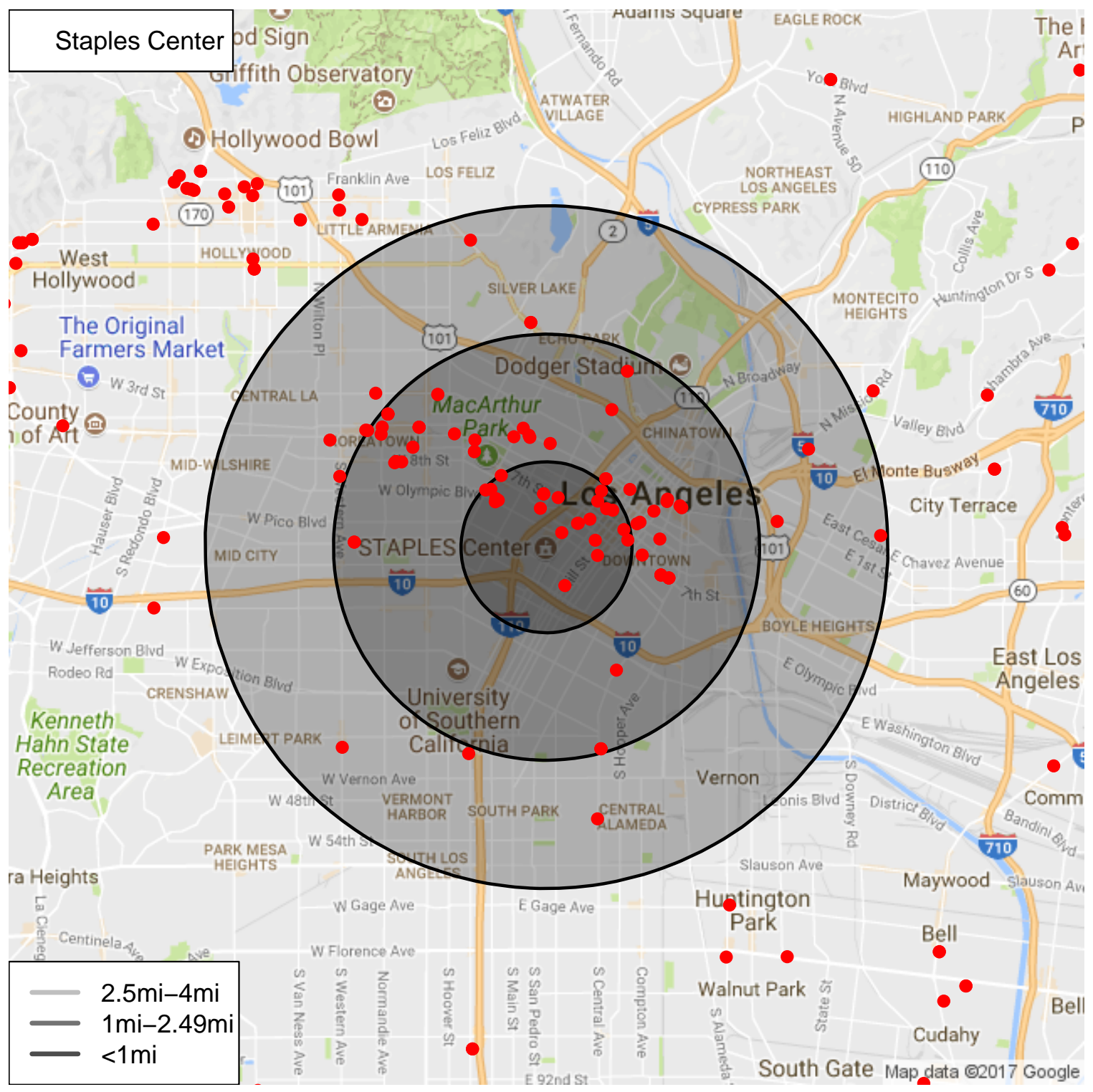

periods also represent plausibly exogenous variation in attendance at nearby professional sporting events. If these periods also have reduced hotel operating performance, this would represent causal evidence that professional sporting events impact nearby hotel operating performance, since the duration of these lockouts is random and the timing unrelated to other economic factors related to demand for hotel rooms.

The concert data come from a list of entertainment events held in the Staples Center. ${ }^{4} 274$ concerts occurred during the period from January 1, 2002 to March 31, 2017. On average, 1.5 concerts were held per month during this time frame, August being the most concert-intensive

\footnotetext{
${ }^{4}$ Available at https://en.wikipedia.org/wiki/List_of_entertainment_events_at_Staples_Center
} 
Table 1: Summary Statistics - Events and Hotel Performance

\begin{tabular}{|c|c|c|c|c|c|}
\hline Variable & Obs & Mean & Std. Dev. & Min & Max \\
\hline \multicolumn{6}{|c|}{ Staples Center Events Data } \\
\hline Lakers Home Games & 16,707 & 0.108 & 0.311 & 0 & 1 \\
\hline Clippers Home Games & 16,707 & 0.108 & 0.311 & 0 & 1 \\
\hline NBA Home Games & 16,707 & 0.203 & 0.402 & 0 & 1 \\
\hline NBA Lockout & 16,707 & 0.029 & 0.168 & 0 & 1 \\
\hline Kings (NHL) Home Games & 16,707 & 0.099 & 0.299 & 0 & 1 \\
\hline NHL Lockout & 16,707 & 0.076 & 0.265 & 0 & 1 \\
\hline Total Home Games & 16,707 & 0.287 & 0.452 & 0 & 1 \\
\hline Lockout & 16,707 & 0.105 & 0.306 & 0 & 1 \\
\hline Concert & 16,707 & 0.049 & 0.216 & 0 & 1 \\
\hline \multicolumn{6}{|c|}{ Hotel Operating Performance Data } \\
\hline Average Daily Room Rate & 16,160 & 93.42 & 22.77 & 50.50 & 219.80 \\
\hline Occupancy Rate & 16,160 & 69.59 & 14.07 & 22.24 & 98.12 \\
\hline Revenue per Available Room & 16,160 & 66.60 & 26.38 & 12.82 & 212.30 \\
\hline
\end{tabular}

month (3.5 concerts on average).

The bottom panel of Table 1 contains summary statistics for the hotel operating performance data. Revenue and price data were deflated using the Consumer Price Index for All Urban Consumers. The average occupancy rate over the sample period was $70 \%$ and the average daily room rate about $\$ 93$. Revenue per room available was $\$ 66.60$.

Table 2 contains summary statistics for the hotel operating performance variables by distance from the Staples Center, based on the donuts shown on Figure 1.

Table 2: Hotel Performance by Distance from the Staples Center

\begin{tabular}{|c|c|c|c|c|c|}
\hline Variable & Obs & Mean & Std. Dev. & Min & Max \\
\hline \multicolumn{6}{|c|}{ Donut 1: $0-0.99$ Miles } \\
\hline Average Daily Room Rate & 5569 & 107.1452 & 25.9817 & 51.8611 & 219.7995 \\
\hline Occupancy Rate & 5569 & 68.3171 & 16.4678 & 22.2396 & 98.1191 \\
\hline Revenue per Available Room & 5569 & 75.9749 & 32.8678 & 12.8166 & 212.3003 \\
\hline \multicolumn{6}{|c|}{ Donut 2: $1-2.49$ Miles } \\
\hline Average Daily Room Rate & 5568 & 92.8482 & 18.2955 & 53.8694 & 180.1171 \\
\hline Occupancy Rate & 5568 & 68.2441 & 13.2495 & 27.9042 & 97.1746 \\
\hline Revenue per Available Room & 5568 & 64.9752 & 23.5931 & 16.1561 & 171.7748 \\
\hline \multicolumn{6}{|c|}{ Donut 3: $2.5-3.99$ Miles } \\
\hline Average Daily Room Rate & 5023 & 78.8275 & 11.2630 & 50.4966 & 130.0207 \\
\hline Occupancy Rate & 5023 & 72.5066 & 11.3620 & 37.5463 & 94.5742 \\
\hline Revenue per Available Room & 5023 & 58.0192 & 15.8044 & 22.7489 & 117.9170 \\
\hline
\end{tabular}

The Staples Center/LA Live complex is a major tourist center, and the spatial variation in hotel operating performance suggests the presence of this complex affects nearby hotels. Occupancy rates are slightly lower in the two donuts closer to the complex, but this may reflect the relatively high occupance rate in Donut 3, which is located farthest from the complex. Average daily room 
rates and revenue per room available are uniformly higher in donuts located closer to the Staples Center/LA Live complex.

Spatial patterns in hotel operating performance suggest that the Staples Center/LA Live complex represents a significant tourist attraction, as hotel operating performance increases with proximity to this complex. The sports event data exhibit substantial variation within the regular season in the NBA and NHA, which has the potential to generate substantial variation in demand for hotel rooms near the arena if a large number of fans attending NHL and NBA games come from out of town and stay in nearby hotels as part of their game day experience. The empirical analysis focuses on assessing the relationship between the presence of the Staples Center, fan attendance at professional sporting events, and nearby hotel operating performance.

\section{Results}

We estimate the parameters of the regression models defined by Equation (1) and Equation (2) using the OLS estimator correcting the estimated standard errors for heteroscedasticity using the WhiteHuber "sandwich" correction. Fans attending NHL and NBA games may differ in terms of their propensity to stay overnight in hotels near the arena. Because of this, we estimate separate empirical models for NHL and NBA home games, as well as a pooled model that assumes homogeneity of NHL and NBA home games.

Table 3 shows results when the dependent variable is the average daily room rate charged by hotels in the sample. In these models, the variables for the occurrence of home NHL and NBA games and concerts are binary; these variables are equal to one on days when a game or concert occurs and zero otherwise. Columns (1), (3) and (5) contain results for Equation (1); Columns (2), (4) and (6) contain results for Equation (2. All standard errors have been corrected for heteroscedasticity using the Huber-White "sandwich" correction.

The Home Game variable indicates days on which an NHL or NBA home game took place in the Staples Center. There is no evidence that average daily room rates increased on days when the Lakers, Clippers, or Kings were in town. The estimated parameter on the two indicator variables for the donuts around the Staples Center are negative and statistically different from zero in Columns (1), (3) and (5). The omitted area is hotels one mile or less from the Staples Center; the highest average daily room rates in the sample are charged by hotels located close to the Staples Center/LA Live complex.

The Lockout variable identifies days during the NHL and NBA lockouts that occurred periodically throughout the sample period. Average daily hotel room rates were higher during these periods than during the NHL and NBA regular season, and than average daily rates during the off season in these sports. Note that the overall effect of lockouts is driven by the NHL lockouts, not the NBA lockouts.

The Concert variable identifies days when concerts occurred in the Staples Center. Average daily room rates were higher on days when the Staples Center hosted concerts than on days when 
other events were held, or days when the arena was dark. Recall from Table 1 that concerts do not occur as often as NHL and NBA home games.

Columns (2), (4) and (6) contain results from Equation (2), where the home game and concert indicator variables are interacted with the proximity donut indicator variables. These models allow the effect of home games and concerts in the Staples Center to have a different impact on hotel operating performance as hotels get farther from the arena. Equation (1) forces the spatial impact to be the same. The general pattern that emerges from the results in Columns (2), (4) and (6) is that the impact of home games and concerts declines with distance from the arena.

This is clearly the case for concerts. The overall effect of concerts on average daily room rates is positive, but the estimated parameters on the concert $\times$ donut interaction terms are negative and statistically different from zero. Hotels near the arena raise their average daily rates on days with concerts, but hotels more than one mile from the arena lower their average daily room rates on those days.

From the results in Columns (1), (3) and (5), average daily rom rates charged by hotels in the outer two donuts are significantly lower than the average daily room rates charged by hotels within one mile of the arena. This could reflect general proximity to the Staples Center/LA Live complex, the overall quality of hotels in the inner donut, or other unobservable neighborhood characteristics.

Table 4 shows results from Equation (1) and Equation (2) when the dependent variable is the daily occupancy rate for hotels in the sample. From the first row on Table 4, hotel occupancy rates are higher on days when NBA games are played in the Staples Center, and on days when any pro sports game occurs, relative to other days.

At first glance, this suggests that professional sports events improve hotel operating performance in the area. However, these parameter estimates are positive and significant in only Columns (4) and (6), models which have interaction terms with proximity to the arena. The estimated parameters on the concert $\times$ donut terms are not positive, and the overall effect of games on hotel occupancy rates depends on the linear combination of all of the game related variables, not the game indicator variable.

Table 6 contains point estimates and confidence intervals for linear combinations of all the gameand concert-related variables for each regression model. From Table 6, the linear combination of the parameter estimates on the NBA home game indicator and this variable interacted with the two donut indicator variables has a point estimate of -0.552 and a $95 \%$ confidence interval that contains zero. Although occupancy rates in hotels near the arena increase on days of NBA games, occupancy rates in hotels farther away from the arena fall on these days, leading to no overall change in occupancy rates in the area. In other words, NBA games appear to draw guests to hotels closer to the arena from people who otherwise would have stayed farther from the arena on game day, but does not lead to overall increases in hotel occupancy rates in the area.

Interestingly, the results on Table 4 indicate that hotel occupancy was higher during the sports lockouts, particularly during the NHL lockouts, than at other times. If the timing of the lockout periods are uncorrelated with unobservable factors affecting hotel occupancy rates, then these 
Table 3: Regression Results - Average Daily Rate (Home Game Binary Indicator)

\begin{tabular}{|c|c|c|c|c|c|c|}
\hline & $\begin{array}{c}\text { NHL } \\
(1)\end{array}$ & $\begin{array}{c}\text { NHL } \\
(2) \\
\end{array}$ & $\begin{array}{c}\text { NBA } \\
(3) \\
\end{array}$ & $\begin{array}{c}\text { NBA } \\
(4)\end{array}$ & $\begin{array}{c}\text { ALL } \\
(5)\end{array}$ & $\begin{array}{c}\text { ALL } \\
(6)\end{array}$ \\
\hline Home Game & $\begin{array}{l}-0.333 \\
(0.336)\end{array}$ & $\begin{array}{c}0.944 \\
(0.642)\end{array}$ & $\begin{array}{c}-0.311 \\
(0.279)\end{array}$ & $\begin{array}{c}0.700 \\
(0.527)\end{array}$ & $\begin{array}{l}-0.380 \\
(0.264)\end{array}$ & $\begin{array}{c}0.892 \\
(0.478)\end{array}$ \\
\hline Lockout & $\begin{array}{c}1.152^{* *} \\
(0.462)\end{array}$ & $\begin{array}{l}1.148^{* *} \\
(0.461)\end{array}$ & $\begin{array}{c}1.283 \\
(0.692)\end{array}$ & $\begin{array}{c}1.273 \\
(0.693)\end{array}$ & $\begin{array}{c}1.191^{* * *} \\
(0.384)\end{array}$ & $\begin{array}{c}1.190^{* * *} \\
(0.384)\end{array}$ \\
\hline 1 - 2.49 Mile Donut & $\begin{array}{c}-14.30^{* * *} \\
(0.253)\end{array}$ & $\begin{array}{c}-13.98^{* * *} \\
(0.277)\end{array}$ & $\begin{array}{c}-14.30^{* * *} \\
(0.253)\end{array}$ & $\begin{array}{c}-13.90^{* * *} \\
(0.295)\end{array}$ & $\begin{array}{c}-14.30 * * * \\
(0.253)\end{array}$ & $\begin{array}{c}-13.75^{* * *} \\
(0.317)\end{array}$ \\
\hline 2.5 - 3.99 Mile Donut & $\begin{array}{c}-29.87^{* * *} \\
(0.246)\end{array}$ & $\begin{array}{c}-29.48^{* * *} \\
(0.268)\end{array}$ & $\begin{array}{c}-29.85^{* * *} \\
(0.246)\end{array}$ & $\begin{array}{c}-29.28 * * * \\
(0.284)\end{array}$ & $\begin{array}{c}-29.87 * * * \\
(0.246)\end{array}$ & $\begin{array}{c}-28.93^{* * *} \\
(0.303)\end{array}$ \\
\hline 1 - 2.49 Mile Donut * Home Game & & $\begin{array}{c}-1.411^{*} \\
(0.752)\end{array}$ & & $\begin{array}{c}-1.030^{*} \\
(0.615)\end{array}$ & & $\begin{array}{c}-1.242^{* *} \\
(0.544)\end{array}$ \\
\hline 2.5 - 3.99 Mile Donut * Home Game & & $\begin{array}{c}-2.573^{* * *} \\
(0.763)\end{array}$ & & $\begin{array}{c}-2.113^{* * *} \\
(0.616)\end{array}$ & & $\begin{array}{c}-2.721^{* * *} \\
(0.541)\end{array}$ \\
\hline Concert & $\begin{array}{c}1.923^{* * *} \\
(0.435)\end{array}$ & $\begin{array}{c}4.040^{* * *} \\
(1.004)\end{array}$ & $\begin{array}{c}1.876^{* * *} \\
(0.436)\end{array}$ & $\begin{array}{c}4.089 * * * \\
(1.011)\end{array}$ & $\begin{array}{c}1.857^{* * *} \\
(0.437)\end{array}$ & $\begin{array}{c}4.213^{* * *} \\
(1.011)\end{array}$ \\
\hline $1-2.49$ Mile Donut $*$ Concert & & $\begin{array}{c}-3.675^{* * *} \\
(1.172)\end{array}$ & & $\begin{array}{c}-3.762^{* * *} \\
(1.180)\end{array}$ & & $\begin{array}{c}-3.896^{* * *} \\
(1.183)\end{array}$ \\
\hline 2.5 - 3.99 Mile Donut ${ }^{*}$ Concert & & $\begin{array}{c}-2.717^{* *} \\
(1.112)\end{array}$ & & $\begin{array}{c}-2.925^{* * *} \\
(1.120)\end{array}$ & & $\begin{array}{c}-3.243^{* * *} \\
(1.121)\end{array}$ \\
\hline Observations & 16,160 & 16,160 & 16,160 & 16,160 & 16,160 & 16,160 \\
\hline R-squared & 0.715 & 0.715 & 0.715 & 0.715 & 0.715 & 0.716 \\
\hline
\end{tabular}

Note: The dependent variable is Average Daily Rate. All models include year, month, and day-of-week fixed effects.

Robust standard errors in parentheses, ${ }^{* * *} \mathrm{p}<0.01,{ }^{* *} \mathrm{p}<0.05$ 
results imply that lockout periods caused increases in occupancy rates in this sample.

Lockout timing should be uncorrelated with unobservable factors that affect consumer and firm decisions influencing hotel occupancy rates in Los Angeles; lockout timing depends on bargaining between sports leagues and player unions over factors like salary caps and are unrelated to factors in specific areas. One explanation for this increase in occupancy rates is if negative externalities generated by NHL games like traffic, crowds, and noise deter other, non-NHL related visitors from staying over night in hotels near the arena.

Like games, concerts have a positive effect on occupancy rates in hotels close to the arena and generate an offsetting decrease in occupancy rates in hotels located farther from the arena. From Table 6 the overall effect of concerts on occupancy rates in all hotels within four miles of the arena is zero.

Note that the parameter estimate on the outer donut area in Columns (1), (3) and (5) is positive. Hotels in the outer donut around the arena have higher occupancy rates than hotels closer to the arena, other things equal. This could simply reflect the relatively lower average room rates charged in these hotels, as shown on Table 3.

Table 5 shows results from Equation (1) and Equation (2) when the dependent variable is revenue per available room (RevPAR) for hotels in the sample. RevPAR reflects both daily room rates and occupancy, an overall measure of hotel operating performance. In general, these results resemble the results for occupancy rates shown on Table 4. Revenue per available room is higher on days when games are played, based on the positive, significant parameter estimate on the Home game indicator variable in Column (6), which includes days when all NHL and NBA games are played.

But the parameter estimates on the home game $\times$ donut interaction terms are negative and statistically different from zero. From Table 6 , the overall linear combination of these parameters has a point estimate of -2.788 and a $95 \%$ confidence interval of $[-6.42,-1.51]$. The overall effect of home NHL and NBA games on hotels within 4 miles of the Staples Center is negative.

Suppose the overall effect of professional sports games on revenue per available room is ignored, and the positive effect on revenue per available room at hotels within one mile of the arena, an increase of $\$ 1.42$, is considered. From Table 2, hotels within one mile of the arena earned an average revenue per available room of $\$ 107.14$ over the sample period. The increase attributable to professional sports games represents a relatively small $1.3 \%$ increase in revenue per available room on at most 123 nights of the year. The presence of nearby professional sporting events, even in the most heavily utilized arena in North America, has a very small impact on the operating performance of hotels within one mile of the arena.

The results on Table 5 also indicate that concerts have a similar effect on revenue per available room. The parameter estimate on the Concert indicator variable is positive and statistically different from zero. Revenue per available room is higher on days when concerts occur in the Staples Center. However, this increase is confined to those hotels within one mile of the arena. Hotels between one and four miles from the arena earn lower revenue per available room. From Table 
Table 4: Regression Results for Occupancy Rate (Home Game Binary Indicator)

\begin{tabular}{|c|c|c|c|c|c|c|}
\hline & $\begin{array}{c}\text { NHL } \\
(1)\end{array}$ & $\begin{array}{c}\text { NHL } \\
(2)\end{array}$ & $\begin{array}{c}\text { NBA } \\
(3)\end{array}$ & $\begin{array}{c}\text { NBA } \\
(4)\end{array}$ & $\begin{array}{l}\text { ALL } \\
(5)\end{array}$ & $\begin{array}{c}\text { ALL } \\
(6)\end{array}$ \\
\hline Home Game & -0.110 & 0.682 & 0.442 & $0.915^{* *}$ & 0.397 & $1.089^{* * *}$ \\
\hline & $(0.274)$ & $(0.532)$ & $(0.232)$ & $(0.438)$ & $(0.217)$ & $(0.388)$ \\
\hline Lockout & $\begin{array}{l}1.055^{* *} \\
(0.410)\end{array}$ & $\begin{array}{c}1.052^{* *} \\
(0.410)\end{array}$ & $\begin{array}{c}0.507 \\
(0.590)\end{array}$ & $\begin{array}{c}0.503 \\
(0.591)\end{array}$ & $\begin{array}{c}0.948^{* * *} \\
(0.341)\end{array}$ & $\begin{array}{c}0.947^{* * *} \\
(0.340)\end{array}$ \\
\hline $1-2.49$ Mile Donut & $\begin{array}{l}-0.075 \\
(0.204)\end{array}$ & $\begin{array}{c}0.117 \\
(0.223)\end{array}$ & $\begin{array}{l}-0.075 \\
(0.204)\end{array}$ & $\begin{array}{c}0.125 \\
(0.234)\end{array}$ & $\begin{array}{l}-0.075 \\
(0.204)\end{array}$ & $\begin{array}{c}0.232 \\
(0.250)\end{array}$ \\
\hline 2.5 - 3.99 Mile Donut & $\begin{array}{c}3.284^{* * * *} \\
(0.190)\end{array}$ & $\begin{array}{c}3.534^{* * *} \\
(0.208)\end{array}$ & $\begin{array}{c}3.300^{* * *} \\
(0.190)\end{array}$ & $\begin{array}{c}3.601^{* * *} \\
(0.217)\end{array}$ & $\begin{array}{c}3.287^{* * *} \\
(0.190)\end{array}$ & $\begin{array}{c}3.812^{* * *} \\
(0.231)\end{array}$ \\
\hline 1 - 2.49 Mile Donut * Home Game & & $\begin{array}{l}-0.986 \\
(0.651)\end{array}$ & & $\begin{array}{l}-0.520 \\
(0.526)\end{array}$ & & $\begin{array}{l}-0.725 \\
(0.459)\end{array}$ \\
\hline 2.5 - 3.99 Mile Donut * Home Game & & $\begin{array}{c}-1.473^{* *} \\
(0.611)\end{array}$ & & $\begin{array}{c}-0.948 \\
(0.495)\end{array}$ & & $\begin{array}{c}-1.424^{* * *} \\
(0.430)\end{array}$ \\
\hline Concert & $\begin{array}{c}1.385^{* * *} \\
(0.325)\end{array}$ & $\begin{array}{c}2.705^{* * *} \\
(0.685)\end{array}$ & $\begin{array}{c}1.452^{* * *} \\
(0.326)\end{array}$ & $\begin{array}{c}2.802^{* * *} \\
(0.688)\end{array}$ & $\begin{array}{c}1.481^{* * *} \\
(0.326)\end{array}$ & $\begin{array}{c}2.923^{* * *} \\
(0.689)\end{array}$ \\
\hline $1-2.49$ Mile Donut * Concert & & $\begin{array}{c}-1.906^{* *} \\
(0.851)\end{array}$ & & $\begin{array}{c}-1.927^{* *} \\
(0.856)\end{array}$ & & $\begin{array}{c}-2.021^{* *} \\
(0.858)\end{array}$ \\
\hline 2.5 - 3.99 Mile Donut $*$ Concert & & $\begin{array}{c}-2.097^{* * *} \\
(0.794)\end{array}$ & & $\begin{array}{c}-2.169^{* * *} \\
(0.799)\end{array}$ & & $\begin{array}{c}-2.365^{* * *} \\
(0.800)\end{array}$ \\
\hline Observations & 16,160 & 16,160 & 16,160 & 16,160 & 16,160 & 16,160 \\
\hline R-squared & 0.522 & 0.522 & 0.522 & 0.522 & 0.522 & 0.522 \\
\hline
\end{tabular}

Robust standard errors in parentheses, ${ }^{* * *} \mathrm{p}<0.01,{ }^{* *} \mathrm{p}<0.05$ 
6, the total effect of concerts on revenue per available room in hotels within 4 miles of the arena is -4.29 with a $95 \%$ confidence interval of [-7.74,-0.83]. The total effect of concerts in the staples center on hotel operating performance of hotels within four miles of the arena is negative.

The parameter estimates on the donut indicator variables in Columns (1), (3) and (5) indicate that hotels within one mile of the Staples Center/L.A. Live complex earn higher revenue per available room than hotels located farther from the complex. This likely reflects the general economic conditions around the Staples Center/LA Live complex, and the overall tourism effect of this facility. However, bear in mind that the evidence also indicates that professional sporting events do not contribute much, if any, to this operating performance. While sporting events have a modest impact on the operating performance of hotels within one mile of the facility, NHL and NBA games generate decreases in RevPAR at hotels located between one and four miles of the complex.

Table 6 summarizes the estimated total effect of concerts and professional sporting events on hotel performance measures for all hotels within four miles of the Staples Center/L.A. Live complex. Table 6 shows point estimates for linear combinations of parameter estimates on Table 3, Table 4 and Table 5, along with estimated standard errors for these point estimates and $95 \%$ confidence intervals.

Many of the results shown on Table 6 have been discussed above. The key general result on Table 6 is that the total impact of concerts and professional sports events held in the Staples Center on the operating performance of hotels within four miles of the arena is, at best, zero, and in many cases negative.

Sporting events and concerts held in the Staples Center have a small impact on nearby hotels and a negative impact on hotels located between one and four miles of the arena. Recall that L.A. Live opened in 2007; the opening of this entertainment and shopping area could affect hotel demand independently of events in the Staples Center. We do not have any time-varying proxy variables for economic activity taking place in L.A. Live. Instead, we re-estimate Equation (1) with an indicator variable that is equal to one after the opening of L.A. Live in 2007. Inclusion of this variable, which assumes that the impact of L.A. Live on nearby hotels was the same in each year following the opening, did not change any of the parameter estimates or estimated standard errors on the sports and concert related variables reported above. Our results are robust to the inclusion of a variable controlling for the opening of L.A. Live.

\section{Conclusions}

We analyze the impact that regular season professional sports events and concerts held at the Staples Center in Los Angeles have on the operating performance of nearby hotels. As part of this analysis, we look at lockouts and work stoppages which represent natural experiments for assessing this impact. If hotel operating performance declines during these periods, this would represent evidence that professional sporting events do impact nearby hotels.

We find that the average daily room rates (ADR) do not increase on days when the Lakers, 
Table 5: Regression Results - Revenue per Available Room (Home Game Binary Indicator)

\begin{tabular}{|c|c|c|c|c|c|c|}
\hline & $\begin{array}{l}\text { NHL } \\
(1)\end{array}$ & $\begin{array}{l}\text { NHL } \\
(2)\end{array}$ & $\begin{array}{c}\text { NBA } \\
(3)\end{array}$ & $\begin{array}{c}\text { NBA } \\
(4)\end{array}$ & $\begin{array}{l}\text { ALL } \\
(5)\end{array}$ & $\begin{array}{l}\text { ALL } \\
(6)\end{array}$ \\
\hline Home Game & $\begin{array}{l}-0.457 \\
(0.475)\end{array}$ & $\begin{array}{c}1.203 \\
(0.956)\end{array}$ & $\begin{array}{c}0.156 \\
(0.397)\end{array}$ & $\begin{array}{c}1.057 \\
(0.782)\end{array}$ & $\begin{array}{c}0.061 \\
(0.373)\end{array}$ & $\begin{array}{l}1.415^{* *} \\
(0.701)\end{array}$ \\
\hline Lockout & $\begin{array}{c}1.599^{* *} \\
(0.652)\end{array}$ & $\begin{array}{c}1.593^{* *} \\
(0.650)\end{array}$ & $\begin{array}{c}1.296 \\
(0.984)\end{array}$ & $\begin{array}{c}1.289 \\
(0.986)\end{array}$ & $\begin{array}{c}1.568^{* * *} \\
(0.543)\end{array}$ & $\begin{array}{c}1.565^{* * *} \\
(0.543)\end{array}$ \\
\hline 1 - 2.49 Mile Donut & $\begin{array}{c}-11.00^{* * *} \\
(0.366)\end{array}$ & $\begin{array}{c}-10.56^{* * *} \\
(0.401)\end{array}$ & $\begin{array}{c}-11.00^{* * *} \\
(0.366)\end{array}$ & $\begin{array}{c}-10.54^{* * *} \\
(0.424)\end{array}$ & $\begin{array}{c}-11.00^{* * *} \\
(0.366)\end{array}$ & $\begin{array}{c}-10.32^{\text {*** }} \\
(0.454)\end{array}$ \\
\hline 2.5 - 3.99 Mile Donut & $\begin{array}{c}-19.84^{* * *} \\
(0.344)\end{array}$ & $\begin{array}{c}-19.28^{* * *} \\
(0.376)\end{array}$ & $\begin{array}{c}-19.82^{* * *} \\
(0.344)\end{array}$ & $\begin{array}{c}-19.21^{* * *} \\
(0.394)\end{array}$ & $\begin{array}{c}-19.84^{* * *} \\
(0.344)\end{array}$ & $\begin{array}{c}-18.79^{* * *} \\
(0.420)\end{array}$ \\
\hline 1 - 2.49 Mile Donut * Home Game & & $\begin{array}{l}-1.961 \\
(1.121)\end{array}$ & & $\begin{array}{l}-1.040 \\
(0.912)\end{array}$ & & $\begin{array}{l}-1.458 \\
(0.802)\end{array}$ \\
\hline 2.5 - 3.99 Mile Donut * Home Game & & $\begin{array}{c}-3.205^{* * *} \\
(1.067)\end{array}$ & & $\begin{array}{c}-1.746^{* *} \\
(0.872)\end{array}$ & & $\begin{array}{c}-2.745^{* * *} \\
(0.761)\end{array}$ \\
\hline Concert & $\begin{array}{c}2.893^{* * *} \\
(0.601)\end{array}$ & $\begin{array}{c}6.213^{* * *} \\
(1.393)\end{array}$ & $\begin{array}{c}2.927^{* * *} * \\
(0.603)\end{array}$ & $\begin{array}{c}6.291^{* * *} \\
(1.400)\end{array}$ & $\begin{array}{c}2.935^{* * *} * \\
(0.603)\end{array}$ & $\begin{array}{c}6.486^{* * *} \\
(1.402)\end{array}$ \\
\hline 1 - 2.49 Mile Donut * Concert & & $\begin{array}{c}-5.111^{* * *} \\
(1.638)\end{array}$ & & $\begin{array}{c}-5.154^{* * *} \\
(1.649)\end{array}$ & & $\begin{array}{c}-5.345^{* * *} \\
(1.652)\end{array}$ \\
\hline 2.5 - 3.99 Mile Donut * Concert & & $\begin{array}{c}-4.946^{* * *} \\
(1.512)\end{array}$ & & $\begin{array}{c}-5.030^{* * *} \\
(1.521)\end{array}$ & & $\begin{array}{c}-5.426^{* * *} \\
(1.523)\end{array}$ \\
\hline Observations & 16,160 & 16,160 & 16,160 & 16,160 & 16,160 & 16,160 \\
\hline R-squared & 0.576 & 0.577 & 0.576 & 0.576 & 0.576 & 0.577 \\
\hline
\end{tabular}

Dependent variable: Revenue per Available Room. All models include year, month, and day-of-week fixed effects.

Robust standard errors in parentheses, ${ }^{* * *} \mathrm{p}<0.01,{ }^{* *} \mathrm{p}<0.05$ 
Table 6: Total Effects of Events on Hotel Performance

\begin{tabular}{lcccccc}
\hline \multicolumn{6}{c}{ Average Daily Room Rate } & \multicolumn{3}{c}{ Occupancy Rate } & \multicolumn{2}{c}{ Revenue per Available Room } \\
& Coef. & {$[95 \%$ Conf. Int.] } & Coef. & {$[95 \%$ Conf. Int. $]$} & Coef. & {$[95 \%$ Conf. Int. $]$} \\
\hline NHL Home Games & $-3.041^{* * *}$ & {$[-4.777,-1.305]$} & $-1.777^{* *}$ & {$[-3.219,-0.334]$} & $-3.963^{* * *}$ & {$[-6.419,-1.507]$} \\
& $(0.886)$ & & $(0.736)$ & & $(1.253)$ & \\
Concerts & $-2.352^{*}$ & {$[-4.839,0.136]$} & -1.298 & {$[-3.150,0.554]$} & $-3.844^{* *}$ & {$[-7.265,-0.422]$} \\
& $(1.269)$ & & $(0.945)$ & & $(1.745)$ & \\
& & & & & & \\
\hline NBA Home Games & $-2.444^{* * *}$ & {$[-3.862,-1.026]$} & -0.552 & {$[-1.725,0.6214]$} & $-1.728^{*}$ & {$[-3.751,0.295]$} \\
& $(0.723)$ & & $(0.599)$ & & $(1.032)$ & \\
Concerts & $-2.597^{* *}$ & {$[-5.102,-0.093]$} & -1.294 & {$[-3.158,0.571]$} & $-3.893^{* *}$ & {$[-7.336,-0.449]$} \\
& $(1.278)$ & & $(0.951)$ & & $(1.757)$ & \\
\hline \multirow{2}{*}{ Home Games } & $-3.070^{* * *}$ & {$[-4.329,-1.812]$} & $-1.060^{* *}$ & {$[-2.093,-0.027]$} & $-2.788^{* * *}$ & {$[-4.575,-1.001]$} \\
& $(0.642)$ & & $(0.527)$ & & $(0.912)$ & \\
Concerts & $-2.926^{* *}$ & {$[-5.437,-0.414]$} & -1.462 & {$[-3.331,0.406]$} & $-4.285^{* *}$ & {$[-7.737,-0.832]$} \\
& $(1.281)$ & & $(0.953)$ & & $(1.761)$ & \\
\hline
\end{tabular}


Clipper, or Kings are in town. In contrast to this, the ADR is higher on days when the Staples Center hosted concerts. Although hotels near the arena increase their ADR on concert days, hotels more than a mile away from the arena tend to lower their ADR on those days.

We also find that the ADR and revenue per available room (RevPAR) is higher during lockouts/work stoppages in the NHL and NBA than when games are being played. This result casts doubt on the idea that professional sports can be an effective driver of local economic development. If professional sports generate important local economic benefits, for example increased demand for hotel rooms in a specific urban area, then these benefits should decline during periods when games do not occur. Higher ADR and RevPAR during lockouts suggests that demand for hotel rooms near the arena increased during periods when games did not occur. This could occur if game attendees are locals and the increased crowds and traffic on games days deterred some tourists from visiting the Staples Center/L.A. Live area.

In contrast to ADR metric, professional sports events and concerts increase occupancy rates as well as RevPAR for hotels close to the arena. The increase in RevPAR is economically negligible $(1.3 \%)$ at best for sports events but is statistically significant for concerts. However, there is an offsetting decrease in occupancy rates and RevPAR for hotels located farther away so there is no overall change in occupancy rates and RevPAR in the area.

Our findings have important public finance implications. In particular, it provides no support for the idea that hotel room taxes should be used to finance new sports facility construction projects. While nearby hotels can benefit from sporting events and concerts in an arena, reductions in operating performance at other nearby hotels implies an uncertain overall impact on hotel tax revenues. In the case of the Staples Center/L.A. Live complex, the granting of waivers from the Los Angeles TOT hotel tax to hotels located near this tourism center reduced the likelihood of an increase in total hotel tax revenues from the opening of the Staples Center/L.A. Live complex. The city granted tax exemptions to hotels that benefited the most from the increased tourism at the Staples Center/L.A. Live complex and, based on our results, hotels subject to this tax experienced lower RevPAR, reducing hotel tax revenues.

The evidence here supports the idea that locating near tourism clusters can improve hotel operating performance (Peiró-Signes et al., 2015). Average daily rates and RevPAR is higher at hotels located near the Staples Center/LA Live complex. This tourism cluster clearly drives increased hotel operating performance likely because of the entertainment and shopping options, and the convention center. But the evidence indicates that professional sporting events do not contribute much to hotel operating performance in addition to these factors. 


\section{References}

Boualam, B. (2014). Does culture affect local productivity and urban amenities? Regional Science and Urban Economics, 46:12 - 17.

Busso, M., Gregory, J., and Kline, P. (2013). Assessing the incidence and efficiency of a prominent place based policy. The American Economic Review, 103(2):897-947.

Carlino, G. and Coulson, N. E. (2004). Compensating differentials and the social benefits of the NFL. Journal of Urban Economics, 56(1):25-50.

Cohen, J. P. and Brown, M. (2017). Does a new rail rapid transit line announcement affect various commercial property prices differently? Regional Science and Urban Economics, 66:74-90.

Collins, C. G. and Stephenson, E. F. (2016). Using hotel occupancy data to evaluate the efficacy of sports tourism: The case of Rome, Georgia. Working paper, Berry College.

Depken II, C. A. and Stephenson, E. F. (2016). Hotel demand before, during, and after: Evidence from Charlotte, North Carolina. Working paper, UNC Charlotte Department of Economics.

Dermody, M. B., Taylor, S. L., and Lomanno, M. V. (2003). The impact of NFL games on lodging industry revenue. Journal of Travel \& Tourism Marketing, 14(1):21-36.

Hua, N. and Yang, Y. (2017). Systematic effects of crime on hotel operating performance. Tourism Management, 60:257-269.

Humphreys, B. R. and Nowak, A. (2017). Professional sports facilities, teams and property values: Evidence from NBA team departures. Regional Science and Urban Economics, 66:39-51.

Kosová, R. and Enz, C. A. (2012). The terrorist attacks of 9/11 and the financial crisis of 2008: The impact of external shocks on US hotel performance. Cornell Hospitality Quarterly, 53(4):308-325.

Kosová, R., Lafontaine, F., and Perrigot, R. (2013). Organizational form and performance: evidence from the hotel industry. Review of Economics and Statistics, 95(4):1303-1323.

Lavoie, M. and Rodrguez, G. (2005). The economic impact of professional teams on monthly hotel occupancy rates of Canadian cities. Journal of Sports Economics, 6(3):314-324.

Montolio, D. and Planells-Struse, S. (2016). How time shapes crime: The temporal impacts of football matches on crime. Regional Science and Urban Economics, 61:99-113.

Nitsch, V. and Wendland, N. (2017). The IOCs midas touch: Summer Olympics and city growth. Urban Studies, 54(4):971-983.

Peiró-Signes, A., Segarra-Oña, M.-d.-V., Miret-Pastor, L., and Verma, R. (2015). The effect of tourism clusters on US hotel performance. Cornell Hospitality Quarterly, 56(2):155-167. 
Rishe, P. J. (2014). Do mobile sporting events produce net increases in tourism, local hotel revenues, and overall economic impact? evidence using STR data. Mustang Journal of Business and Ethics, $7: 17-33$. 